\title{
TARTU RADIOCARBON DATES II
}

\author{
J. M. PUNNING, E. ILVES, AND A. LIIVA
}

Institute of Zoology and Botany, Academy of Sciences, Listonian S.S.R.

The following list includes samples dated between 1956 and 1961. Wood dating from A.D. $1850 \pm 10 \mathrm{yr}$ is used as a contemporary reference standard. Background sample is synthesized from anthracite. All radiocarbon dates were calculated with the half-life of $\mathrm{C}^{1+1}$ being equal to $5568 \pm 30$ yr. All dates are calculated from the year 1950 .

Sample synthesis and measurement methods are described in Tartu Radiocarbon Dates I (Liiva, et al., 1966) except for TA-99, 100, and 101. For their clating, benzene was synthesized in a larger amount and a scintillator solution composed of PPO $4 \mathrm{~g} / \mathrm{l}+$ POPOP $0.1 \mathrm{~g} / \mathrm{l}+$ naphthalene $100 \mathrm{~g} / \mathrm{l}$ in benzene was used. When $40 \mathrm{ml}$ of this solution was used, rate of the background was $6.32 \pm 0.04$ counts $/ \mathrm{min}$, the count of the contemporary reference standard being $183.53 \pm$ counts $/ \mathrm{min} \pm 0.30$ counts/min. The maximum determinable age is equal to 52,500 yr $(=$ 48 hours counting 45 (riterion) (Pumning, et al., 1966).

I. ARCHAEOLOCIC: SAMPLES

$$
2520 \pm 60
$$

TA-81. Asva

570 в.c.

Charcoal from lower horizon of cultural layer of fortified settlement Asva, Is. Saaremaa, Kingissepp District, Estonian SSR near present village Asva at depth of 95 to $45 \mathrm{~cm}$ below surface near $S$ wall. Presumably late Bronze age (corresponding to the 5 th period in Mentelius system), 8th to 6th c. B.c. Coll. 1965 and subm. by V. Longas (Inst. of Hist., Acad. of Sci. of Estonian SSR).

\section{TA-82. Valgjärv}

$1370 \pm 60$

Wood from ancient dwellings on Valgjärv ("White Lake"), Valga District, Estonian SSR, $3 \mathrm{~km} \mathrm{~S}$ of settlement Koorküla. According to archaeol. data (Selirand, 1960), samples are remains of peculiar, fortified settlement in middle of lake. According to popular belief, monument is linked to legend of origin of lake whose waters inundated farms. (Eisen, 1958). Presumable age of sample, 2nd half of 1st millennium A.D. Coll. 1958 and subm. by J. Selirand (Inst. of Hist.).

\section{TA-84. Torva}

$1370 \pm 75$ A.D. 580

Charcoal from lower horizon of cultural layer found in NW part of outer defense works in Tórva township, Valga District, Estonian SSR, $11 / 2 \mathrm{~km} \mathrm{~S}$ of Torrva. Sample coll. at clepth of 90 to $110 \mathrm{~cm}$. Layer immediately underlies grass cover and extends 60 to $130 \mathrm{~cm}$ below ground surface. Presumable age of sample, 6th to 7 th c. A.D. Coll. 1965 and 
subm. by H. Moora jun. (Viljandi Interdistrict Mus. of Regional Studies).

TA-104. Paatsa

$670 \pm 60$

A.D. 1280

Charred wood from dwelling remains of Paatsa township village soviet Võhma, near the center of Paatsa, Kingissepp District, Estonian SSR. Sample coll. in NW part of township at depth of 30 to $40 \mathrm{~cm}$ below ground surface and is attributed to the latest period of township. According to A. Kustin, township existed in 12th to 13th c. A.D., maybe as late as 14th century. Coll. 1963 and subm. by A. Kustin (Inst. of Hist.).

\section{TA-108. Rauasaatme mäed}

$600 \pm 60$

Charcoal from dump of metal slag $3 \mathrm{~km} \mathrm{E}$ of township Paatsa (cf. TA-104) in Kingissepp District, Estonian SSR. Dumps are remains of single melting of iron ore with charcoal. Bog-iron ore probably served as raw material (Aalose, Kustin, 1966). Ceramics discovered near slag dump similar in form to late ceramics from Paatsa township. Presumable age of sample, 2nd half of 13th or 14th c. Coll. 1962 by A. Kustin and A. Aaloe; subm. by A. Kustin.

\section{TA-105. Usvyata}

$4570 \pm 70$

Wood from Neolithic settlement Usvyata IV on S outskirts of settlement Usvyata, Nevel' District, Pskov Region, RSFSR. Sample coll. from lower horizon of cultural layer (B) at $125 \mathrm{~cm}$ below surface, is fragment of pile settlement dwelling. Pollen analyses by E. A. Spiridonov refer Layer $\mathrm{B}$ to Atlantic period. Presumable archaeol. age, end of 3rd or beginning of 2nd millennium B.c., maybe older. Coll. 1964 and subm. by A. M. Miklyayev (State Hermitage of SSSR).

\section{GFOLOGIG SAMPLES}

\section{TA-74. Piihajärv}

$3300 \pm 60$

1350 B.c.

Plant remains near Lake Pühajärv, Valga District, Estonian SSR, at depth of 1.30 to $2.20 \mathrm{~cm}$ below surface. Coll. 1964 and subm. by K. Kajak (Geological Board attached to Council of Ministers of Estonian SSR, later referred to as Geol. Board).

\section{TA-75. Altküla}

$8460 \pm 180$

\section{B.C.}

Silvan, dark brown peat from Haapsalu District, Estonian SSR. Underlying varved clays, protective layer-clayey aleurite with plant remains, sample was at depth of 125 to $135 \mathrm{~cm}$. Presumable age, $Q_{\mathrm{IV}}$ Ancylus. Coll. 1964 and subm. by H. Stumbur (Geol. Board).

\section{TA-77. Voidu}

$$
9100 \pm 90
$$

Buried wood peat from Kilingi-Nõmme District, Estonian SSR at depth of 520 to $527 \mathrm{~cm}$. Layer of peat rests on moraine, overlain by 
clayey sapropelite, followed by littoral deposits of Lake Ancylus. Coll. 1965; subm. by Prof. K. Orviku; pollen-dated by H. Kessel (1963a).

TA-78. Tapu

$8995 \pm 125$

7045 B.C.

Buried wood peat from Pärnu District ( $\mathrm{N}$ of settlement PärnuJaagupi), Estonian SSR, at depth of 194 to $199 \mathrm{~cm}$. Sequence described in TA-77. Coll. by H. Kessel and E. Ilves. Pollen analysis by H. Kessel (1963b).

\section{TA-79. Erdi}

$\mathbf{7 0 0 0} \pm \mathbf{8 0}$

5050 B.c.

Silvan low-lying peat from peat-bog Erdi, Viljandi District, Estonian SSR, from layer at depth of 775 to $800 \mathrm{~cm}$. Pollen analysis by E. Liivrand attributes sample to Pollen Zone VIII (V. Post-Nilsson system). Coll. 1965 by $\mathrm{H}$. Liivrand; subm. by K. Kajak.

\section{TA-80. Kolga-Jaani}

$\mathbf{8 2 2 5} \pm \mathbf{8 0}$

Peat at depth of $100 \mathrm{~cm}, 3 \mathrm{~km}$ NE of Kolga-Jaani, Viljandi District, Estonian SRR. Coll. 1965 and subm. by K. Kajak.

\section{Endla series}

Samples coll. from high moor Teosaare, incorporated in bog system Endla (1.5 km NE of settlement Kärde, Jõgeva District, Estonian SSR).

Table 1. Stratigraphy of Endla Bog System

\begin{tabular}{|c|c|c|}
\hline Depth $(\mathrm{cm})$ & Sediment type & $\begin{array}{c}\text { Degree of } \\
\text { decomposition } \\
\text { (humification } \% \text { ) }\end{array}$ \\
\hline to 105 & sphagnum peat & 15 \\
\hline 105 to 120 & wood and reed peat & 20 \\
\hline 120 to 220 & wood peat & 35 to 50 \\
\hline 220 to 250 & wood and reed peat & 25 to 30 \\
\hline 250 to 390 & reed peat & 20 to 30 \\
\hline 390 to 407 & wood and reed peat & 70 to 80 \\
\hline 407 to 415 & moraine & \\
\hline $415+$ & limestone & \\
\hline
\end{tabular}

Coll. 1965 by E. Ilves. Pollen analyses (according to V. Post-Nilsson system) were carried out by A. Sarv.

TA-85. Endla

$$
1145 \pm 65
$$
A.D. 805

Sphagnum peat at depth of 55 to $60 \mathrm{~cm}$. The boundary-line of Pollen Zones Ib/Ia.

TA-86. Endla

$1260 \pm 65$

\section{A.D. 690}

Sphagnum peat at depth of 90 to $95 \mathrm{~cm}$. Upper maximum of spruce. 
TA-87. Endla

$1670 \pm 110$

Sphagnum peat passing over into wood and reed peat at depth of 100 to $105 \mathrm{~cm}$. Border of Pollen Zones II/Ib.

TA-88. Endla

$2855 \pm 70$ III $/$ II

Wood peat at depth of 155 to $160 \mathrm{~cm}$. Boundary of Pollen Zones

TA-89. Endla

$3125 \pm 70$

Wood peat at depth of 175 to $180 \mathrm{~cm}$. Lower maximum of spruce.

\section{TA-90. Endla}

$3465 \pm 70$

1515 B.C. IV/III.

Wood peat at depth of 190 to $195 \mathrm{~cm}$. Boundary of Pollen Zones

TA-91. Endla

$3935 \pm 70$

1985 B.c.

Wood peat at depth of 205 to $210 \mathrm{~cm}$. Maximum of oak Pollen.

TA.92. Endla

$4265 \pm 70$

2315 B.c.

Wood and reed peat at depth of 220 to $225 \mathrm{~cm}$. Boundary of Pollen Zones $\mathrm{V} / \mathrm{IV}$.

TA-93. Endla

$4735 \pm 70$

2785 B.C.

Wood and reed peat collected from 230 to $235 \mathrm{~cm}$. Maximum of lime Pollen.

TA-94. Endla

$5245 \pm 70$

3295 в.c.

Wood and reed peat at depth of 245 to $250 \mathrm{~cm}$. Possibly border of Pollen Zones VI/V.

TA.95. Endla

$6480 \pm 70$

4530 в.c. VII/VI.

Reed peat at depth of 305 to $310 \mathrm{~cm}$. Boundary of Pollen Zones

TA-96. Endla

$7865 \pm 75$

5915 B.C.

Wood and reed peat at depth of 370 to $375 \mathrm{~cm}$. Boundary of Pollen Zones-VIII/VII.

TA-97. Endla

$8015 \pm 80$

6065 B.C. Pollen.

Wood and reed peat at depth of 375 to $380 \mathrm{~cm}$. Maximum of pine

TA-98. Endla

$8495 \pm 85$

6545 B.C.

Wood and reed peat at depth of 394 to $400 \mathrm{~cm}$. Pollen Zone VIII. 
TA-109. Endla

$$
6180 \pm 90
$$

Reed peat at depth of 275 to $280 \mathrm{~cm}$. Maximum of elm Pollen.

\section{Karuküla series}

Intermorainic deposits of Karuküla are situated in SW of Estonian SSR, $7 \mathrm{~km} \mathrm{~S}$ of town Kilingi-Nõmme. Samples taken from wall of prospecting shaft. Structure of section: humic horizon of soil; rubbly sandy loam (moraine); organogenous layer, $140 \mathrm{~cm}$ thick (arboreal peat with wood remains, equisetic peat, clayey sapropelite); aleurite. Pollen analyzed by $\mathrm{R}$. Pirrus showed changes in climate from severe to warm and back to severe (Orviku and Pirrus, 1965). Coll. 1965 and subm. by K. Kajak (Punning, et al., 1966).

\section{TA-99. Karukuila}

$33,450 \pm 800$

Wood remains at depth of 150 to $170 \mathrm{~cm}$.

\section{TA-100. Karuküla}

Peat at depth of 150 to $170 \mathrm{~cm}$.

\section{TA-101. Karuküila}

31,500 в.c.

Peat at depth of 195 to $215 \mathrm{~cm}$.

TA-106. Karuküla

Clayey sapropelite at depth of 235 to $255 \mathrm{~cm}$.

$48,100 \pm 1700$

46,150 в.C.

$48,100 \pm 1650$

46,150 в.c.

TA-102. Kivilope

Peat from boggy plain of Lake Võrtsjärv $7 \mathrm{~km} \mathrm{E}$ of Mustla, Viljandi District, Estonian SSR. Sample lay on lake silt at depth of 170 to $210 \mathrm{~cm}$. Pollen analysis by E. Liivrand. Sample is referred to Pollen Zone II (V. Post-Nilsson system). Coll. 1965 and subm. by K. Kajak.

\section{TA-122. Lemmeoja}

$9240 \pm 85$ 7290 в.c.

Gravelly sapropelite from bottom of gravel pit $20 \mathrm{~m}$ from right bank of stream Lemmeoja, Pärnu District, Estonian SSR. Coll. at depth of 38 to $44 \mathrm{~cm}$, sapropelite underlies bank deposits of Lake Ancylus. Pollen analyzed by N. Kessel. Coll. 1966 by J. M. Punning; subm. by K. Kajak.

\section{TA-123. Lemmeoja}

$9100 \pm 85$

Wood from bottom of gravel pit $20 \mathrm{~m}$ from right bank of stream Lemmeoja, Pärnu District, Estonian SRR (see: TA-122). Coll. at depth of 45 to $49 \mathrm{~cm}$.

TA-124. Ula

$$
11,930 \pm 110
$$

$$
9,980 \text { в.C. }
$$

Wood remains from valley of river Ula near village Zervinus SW of city Vilnius, Vilnius District, Lithuanian SSR. Wood remains and peat 
lie in middle of thick complex of sand. Sample coll. from layer of blackgray humified clay containing shells of mollusks. Coll. 1966 by J. M. Punning, L. Serebryanny, and R. Pirrus; subm. by K. Kajak. Comment: Lab. of V. I. Vernadsky Institute of Geochemistry and Analytical Chemistry (MO-302) dated sample at $16,260 \pm 640$.

\section{TA-125. Ula}

$12,160 \pm 120$

Mossy peat from valley of river Ula near Zervinus, taken from same layer as TA-124.

\section{TA-126. Kolga}

$7505 \pm 165$

Clayey sapropelite with remains of bulrushes on right bank of river Kolga, Pärnu District, Estonian SSR. Sapropelic layer, $18 \mathrm{~cm}$ thick, underlies 10-cm-thick dunes of Littorina Sea. Sample depth 0 to $3 \mathrm{~cm}$ (with reference to dune). Coll. 1966 by J. M. Punning; subm. by K. Kajak.

\section{TA-127. Virunurme}

$5880 \pm 60$

Peat from peat bog Virunurme, Kohtla-Järve District, Estonian SRR at depth of 630 to $680 \mathrm{~cm}$. Coll. 1966 by J. Paap; subm. by K. Erisalu (Geol. Board).

\section{TA-128. Sarkanais mals}

$$
10,390 \pm 105
$$

Wood remains of brick quarry "Sarkanais mals" on right bank of river Melune, Jelgava District, Latvian SSR at depth of 220 to $240 \mathrm{~cm}$. Wood remains overlain by soil and sand, and underlain by varved clays and moraine. Pollen analyzed by V. Stelle. Sample assigned to Pollen Zone X (V. Post-Nilsson system), (V. J. Stelle, 1963). Coll. 1965 and subm. by V. Stelle (Inst. of Geol., Latvian SSR).

\section{TA-129A. Progress}

$11,950 \pm 110$

Plant remains from a brick quarry "Progress" on right bank of river Lielupe, Jelgava District, Latvian SSR. Sample lay in sand plain, at depth of $300 \mathrm{~cm}$, overlying varved clay (V. Stelle, 1963). Coll. 1965 and subm. by V. Stelle.

\section{TA-129B. Progress}

$11,875 \pm 110$

Control dating of the sample TA-129.

\section{TA-131. Bolotnitsa}

$$
\begin{array}{r}
1330 \\
\text { A.D. } 620
\end{array}
$$

Wood and plant remains from an outcrop on river Bolotnitsa 1.2 $\mathrm{km}$ from village Bolotnitsa, Leningrad Region, RSFSR. Borderline horizon of peat bog. Sample taken at depth of $50 \mathrm{~cm}$. Coll. 1966 and subm. by L. Serebryanny (Inst. of Geogr., Acad. Sci., USSR). 


\section{TA-132. Vitka}

Submorainic peat near village Vitka, $5 \mathrm{~km}$ SE of town Vastseliina, Võru District, Estonian SSR at depth of 3.7 to $4.0 \mathrm{~m}$. Coll. 1964 and subm. by K. Kajak.

\section{TA-133. Oara}

Peat sapropelite near river Oara, Pärnu District, Estonian SSR at depth of 154 to $163 \mathrm{~cm}$. Sapropelic layer, $28 \mathrm{~cm}$ thick, underlies aleurite and overlies varved clays. Pollen analyzed by $\mathrm{H}$. Kessel, sample assigned to Pollen Zone IX (V. Post-Nilsson system). Coll. 1966 by J. M. Punning; subm. by K. Kajak.

\section{REFERENCES}

Aaloe, A. and Kustin, A., 1966, Ancient metallurgy i nSaaremaa: Eesti Loodus, no. 3, p. 162-164 (in Estonian)

Eisen, M. J., 1958. Esivanemate varandus: Tallinn, p. 9 (in Estonian) .

Kessel, H., 1963a, Age of transgression of the Baltic Holocenic basins in Estonia on the basis of palynological data: Baltica I, Vilnius, v. 1, p. 104 (in Russian). 1963b, Holocene coastal formations on the coast of south-west Estonia: ENSV TA Geoloogia Instituudi uurimused, v. 12, p. 123-144 (in Russian).

Orviku, K., and Pirrus, R., 1965, Intermorainic organogenic deposits of Karuküla, Estonian SSR: Limnologiya i stratigrafiya tchetvertitschnykh otlozhenii Estonii, Tallinn, p. 3-21 (in Russian).

Punning, J. M., Ilves, E., and Liva, A., 1966, Dating of ancient samples by the radiocarbon method: ENSV TA Toimetised, Bioloogiateaduste seeria, no. 4, p. 577-581 (in Russian).

Selirand, J., 1960, Preliminary results of an archeological study of Valgjärv: ENSV Teaduste Akadeemia Toimetised, v. 9, Ühiskonnateaduste seeria, no. 3, p. 268-276 (in Estonian)

Stelle, V., 1963, Driasa floras augu atliekas kiegelu fabrikas "Progress" apkartne pie Jelgavas: Petera Stuckas Latvijas valsts Universitates zinantniskie raksti. 49. sej. Biologijas zinatnes, 2. Botanika 1, p. 169-175 (in Latvian).

Stelle, V. J., 1963, Late glacial plant remains near Ane in the vicinity of Jelgava: Voprosy tchetvertitchnoi geologii, II, Trudy Instituta geologii, XI, Riga, p. 125132 (in Russian). 